\title{
CROSS-NATIONAL COMPARATIVE STUDY ON LEGAL EDUCATION AND ADMISSION TO PRACTICE BETWEEN CHINA, INDIA AND PAKISTAN
}

\author{
Yu ShuHong \\ Professor, School of Law, Wuhan University, China \\ shuhongy@126.com \\ Tel: +862768753689 \\ Malik Zia-ud-Din \\ (Corresponding author) \\ $\mathrm{PhD}$ candidate at School of Law, Wuhan University, China \\ malikziaudin@yahoo.com \\ Roy Dilawer Khan \\ School of Law, Wuhan University, \\ Wuhan, China \\ Samra Bilal \\ School of Higher Education, China University of Geosciences, \\ Wuhan, China
}

\section{(Received: March 2018; Accepted: May 2018)}

\begin{abstract}
Legal profession has experienced substantial changes owing to economic needs and evolution of legal industry and market. This has multiplied the need of new breed of competent and well versed lawyers in the global legal profession. The character and calibre of the legal profession is determined by the quality and standard of law faculties and of legal education. The study intends to explore and compare the legal education and admission to practice in China, India and Pakistan. It further expounds the structure, purpose, teaching methods, pathways to admission and problems of legal education in all jurisdictions. The research contemplates on the distinctive features of legal education and its compatibility with practical aspect of legal profession in the selected countries. The study finds that China and Pakistan have a similar structure of mandatory training after graduation which India does not provide for. The study concludes that all jurisdictions must include legal practical course into their curriculum to be able to compete with the global demand.
\end{abstract}

Keywords: cross-national, comparative, legal education, admission to practice, China, India, Pakistan

\section{Introduction}

It is self-evident that legal practice has become more globalized so has the legal education. Globalization of legal practice has yielded multipronged activities such 
as increase in cross border activities and changes in the structure and regulation of legal profession (Susskind, 2013). The law schools are, hence, nurturing in their students the ability to face the challenges existing in the global legal practice (Godwin \& Wu, 2016). The law schools are bound to equip their graduates not only with contemporary theoretical knowledge of law but also with enhanced practical skills which are necessary for lawyers, judges and professionals in related fields to act efficiently in globalized context. The globalization of legal education has a significant relationship with legal practice in globalized context. The study particularly examines and focuses on the pathways to admission and the process through which lawyers are licensed by evaluating the practical skills incorporated in the school curriculum.

The study investigates the required legal education and substantial pathways to admission as a lawyer in three countries, China, India and Pakistan. The study further explores the role of both the practical courses in the curriculum of law schools as well as the professional training courses which pursue graduation and precede admission to the bar in developing capability in students to cope with the challenges of legal field. In this regard, many similarities have been observed in all three jurisdictions. However, none of the jurisdictions have introduced Experiential Education for the students to complete as offered to law school students in America by the American Bar Association (Stuckey, 2016). Instead, the law schools are given authority to determine how practical skills should be included in the syllabus (Godwin \& Wu, 2016). Yet, there are some elements of difference among three countries with regard to the scope of design and pathways of admission built on the inherent deficiencies in the teaching of practical skills during academic degree. Therefore, it is necessary to minimize these inefficiencies so that requirements to practice in legal field can be fulfilled. The paper evaluates the development and pathways taken for the admission and discovers several interesting countervailing aspects and differentiations.

The key questions invoked from the comparative analysis are either the professional admission courses should be regarded as gatekeeper with regard to ensuring the quality and competence, or these courses should only be regarded as simply preparatory courses for admission to bar and legal fraternity. The study further contemplates the legal requirement such as training or internship and examination to admission in the selected jurisdictions. The study discloses number of prevailing tendencies and contradictions with reference to essential issues, for instance the purpose of law degree and its impact on legal education and legal practice. It indicates the significance of legal education to strengthen legal practical skills while focusing on precise research skills along with general skills e.g. analytical approach and problem solving techniques. 
Yu ShuHong, Malik Zia-ud-Din, Roy Dilawer Khan, Samra Bilal (2018)

Cross-national comparative study on legal education and admission to practice between China, India and Pakistan

The paper is divided further into five chapters other than introduction. Part 1 contemplates the nexus between legal education and legal practice by analyzing the growing importance of professional legal training and courses and increased demand for the law school to include such courses into the curriculum. Chapters 2, 3 and 4 elaborate the pathways to admission in China, India and Pakistan respectively and argue the significance of practical legal skills and training in each country. Chapter 5 derives some findings of the comparative analysis and draws some inferences from the study.

\section{Nexus between Legal Education and Legal Practice}

Oliver Wendell Holmes expressed that law is not simply a logic, but an experience (Holmes Jr, 1886). The rationale behind this statement refers to the comprehensive expansion and rigorous training of law for the law school students. Because it enhances the legal marketability, fundamentally by building foundation of legal intellect and enhancing the level of legal profession (Pinguelo, 1998). The current question has extreme significance in many countries including United Kingdom, USA and the three jurisdictions selected for this analysis. The emergence of this question is widely recognized for inclusion of the professional training course into the curriculum to prepare law students for admission. It is worth mentioning that at current moment, none of the selected jurisdictions are offering such training courses into their curriculum in legal study at law schools. However, the training courses have significance in legal education and law studies in many neighbouring countries such as Hong Kong and Singapore. Similarly, United Kingdom and Australia have partnership between course provider and the law firms on the design of training course based on the firm's competence and ability for the students' internships at law firms (Faulconbridge \& Muzio, 2009).

There are some factors involved in exploring the professional training courses following graduation and preceding admission. First, there is a need to accomplish consistency in the technical and vocational training and ensure that law graduates have accomplished the minimum level of competency and quality of legal education. The need has grown as the number of law schools and law graduates have increased exponentially, since the role of law degree has pronounced during the past few decades as a liberal art as well as a professional degree (Godwin \& $\mathrm{Wu}, 2016)$. Therefore, the scholars and academicians have argued the purpose of law degree and its impact on the liberalization of economy and society in the context of legal education and justice (Priest, 1988).

The other factors are associated with the changes in the structure of legal practice, mainly in the context of globalization of legal practice and increased competition of legal profession in the context of cost (Arthurs, 2001). The factors related to globalization and competition is considered as the key driver of legal education 

Pakistan

reforms in any jurisdiction. All jurisdictions are reacting to this competition and promising to produce multitalented world class lawyers to compete with their overseas counterparts (Wang, Liu, \& Li, 2016). As a result, many clients are now reluctant to pay junior lawyers "to have practice" on their cases, while in some cases the clients absolutely refuses to pay junior lawyers at all (Godwin \& Wu, 2016). This has created difficulties and has decreased opportunities for the juniors and on job training lawyers, and thus it has increased expectations on the part of law firms that fresh entrants learn faster and compete with their counterparts. In addition, the clients' demand for the professional, skilled and experienced lawyers has increased because the clients value their commercial experience and business advice on any particular issues more than their technical advice. In a business context, the value of lawyers as a business advisor is more pronounced than that as legal advisors (Kosuri, 2015).

In connection with above mentioned factors, there is a strong need to strengthen the practical skills distinctively from the technical knowledge that the law graduates are supposed to receive at law school and imitate those skills in the practical field. Despite the emergence of professional training courses, whether delivered by the law schools or by the vocational education providers, the debate continues on the role of law schools regarding addition of such training courses and skills into the law degree curriculum to be provided to the law students. It has increased the demand of clinical and transactional law programmes within the curriculum alongside existential technique to teach law (Ibid: 488). Thus, it is significant to consider that the demand from law schools have increased to include and deliver the best knowledge and practicing techniques to the law graduates as a requirement of legal fraternity and law firms. Eventually, the law degree is prerequisite to admission to bar and it is therefore reasonable and eloquent that this profession needs such academic requirement for that purpose. Therefore, the critical question to explore is what legal profession should contribute in the teaching of legal practical skills within the curriculum as distinguished from the teaching of doctrinal or substantive law.

\section{Historical background of Legal Education in China}

The modernisation of legal education in China can be traced back to Qing Dynasty during the political reforms (Jiang, 2000). The Qing Dynasty reformers faced severe paucity of modern legal educators; consequently, they invited legal experts from foreign countries to teach law in China and sent Chinese students to foreign countries to study legal education. The beginning of twentieth century witnessed many Japanese legal experts being invited to China to teach legal education and legal counselling (Wang et al., 2016). 
Yu ShuHong, Malik Zia-ud-Din, Roy Dilawer Khan, Samra Bilal (2018)

Cross-national comparative study on legal education and admission to practice between China, India and Pakistan

In 1949, The Chinese Communist Party came into power; the party introduced fundamental changes in the structure of existing legal education of the country during its early years (Gao, 2010). Legal education in China was considerably influenced by and shaped under Soviet legal theories based on old law school curricula, textbooks and teaching style since 1952 to late 1960s (Feineran, 1991; Keyuan, 2003). Soviet-influenced legal education ended during late 1960s as a result of growing political disagreement and confrontation between Soviet Union and China. Legal education was severely paralyzed and significantly ignored during the "Cultural Revolution (1966-1976)" (Lee, 1962). Subsequent to reforms era, the Chinese legal education began recovery process with establishment of numerous law schools which offered highly competitive legal education. The growing number of law schools and students enrolment in law departments necessitated the legal material and law text books -international law, environmental law, economic law and intellectual property law- to be published in Chinese language to be taught in the classrooms (Wang et al., 2016). Chinese law departments/ law schools started delivering academic and professional legal education based on modernized and standardized techniques during the mid 1990s (Ibid: 239). In continuation of professional modern legal education, the two years Juris Master (J.M.) programme modelled on American style J.D programme was launched in 1999 (Ji, 2005).

Meanwhile, keeping in view the educational development, the Ministry of Education formulated a committee in 1997 for the Guidance of Legal Education in Higher Education Institutions. The objective of this committee was to design standardize undergraduate law programme by focusing on fourteen basic law major courses and numerous elective courses to be taught in all Chinese Law schools. These reforms led to burgeoning of law schools and law students in the country (Abramson, 2006). Law major became very popular in the universities as well as legal profession a successful option for the career. Economic development and Open Market Policy flourished the economic activities and multiplied the civil disputes, which further opened a gate for legal profession, law graduates and law firms (Gao, 2010). The end of twentieth century remained fortunate and fruitful for legal education in China.

\subsection{Basic Structure of Legal Education in China}

The Cultural Revolution gave birth to the modern legal education in China about 30 years ago [1] (Zhu, 2009). The 1957 Anti Rightist Campaign had put the country into severe chaos and disturbance till its end at Cultural Revolution. However, under the charismatic leadership of Deng Xiaoping in 1978, the country commenced the efforts for the restoration of legal system, law departments and universities to resume their operations (Phan, 2005). Since then, the mushroom 


\section{$S$ sciendo

Yu ShuHong, Malik Zia-ud-Din, Roy Dilawer Khan, Samra Bilal (2018)

Cross-national comparative study on legal education and admission to practice between China, India and Pakistan

growth of law schools/ law departments, law students and lawyers has been witnessed in China which motivated the country to strengthen the legal institutions to create a "Rule of Law" society (Baskir, 2012).

Similar to many countries, Chinese students also study law as undergraduate field of study at department of law and politics, law schools or law department in universities (He, 2005). Chinese law students begin with four years law degree after the completion of high school education (Ibid: 146-147). Many students acquire Master's degree in Law and some of them receive PhD degree in Law. However, relatively few students pursue their careers as lawyers after completion of undergraduate law degree but most of them prefer to join government positions or business (Minzner, 2013). Furthermore, surprisingly the law degree is not required to become a licensed lawyer in China; the undergraduate degree holder in any major or candidates having a certain years of legal experience can sit in the Chinese Bar Examination which is officially known as National Judicial Examination (Law of the People's Republic of China on Lawyers, 2007 § \& 8).

The law Professors impart the knowledge of law and legal theories by lectures while the students learn law material and legal theories by memorizing such laws as much as possible (Ling, 2006). Mostly, the students are unreceptive during the lectures, because their exam is designed to judge their ability to memorize and replicate the information in large quantity which was delivered in the class (Zhu, 2009). As a consequence, the undergraduate study of legal education has failed to address and strengthen the students' professional ability, practical skills and training; instead it has emphasized on "legal article, legal principle, legal philosophy" (Ling, 2006).

The curriculum of undergraduate law degree programme is substandard with fourteen domestically prescribed law courses (Xianyi, 2001) along with a long list of general courses such as "Marxist Theory and Ideology and Morality" (Abramson, 2006). The duration of undergraduate law degree is four years which requires 140-170 credit hours for approximately 50 or more courses [2] (Baskir, 2012). The undergraduate law programme's students usually take six to eight courses in a semester which requires them to spend fifteen to twenty hours in the classroom during one week (Phan, 2005). Furthermore, Chinese law students spend more time on class lectures and taking notes and less time on preparing assignments outside of class (Baskir, 2012). Moreover, legal education has been distributed in three hierarchal levels in China which are undergraduate (LLB), Masters (LL.M, J.M) and doctoral programmes (LL.D. or PhD) (Erie, 2009). Generally, undergraduate law students can pursue higher education e.g. LL.M. degree which primarily focuses on research and professional skills and requires students to write thesis in a particular field of law (Xianyi, 2001). After completion 
Yu ShuHong, Malik Zia-ud-Din, Roy Dilawer Khan, Samra Bilal (2018)

Cross-national comparative study on legal education and admission to practice between China, India and Pakistan

of Master's degree in law, students can continue their studies to pursue doctoral law studies (LL.D.) (Landsberg, 2011).

Legal Education in China has developed rapidly and became very famous and high demand major in the universities and colleges during 1990s (Ji, 2005). The traditional Chinese legal education failed to provide future competent legal professionals. Therefore, the Ministries of Justice and Education have taken initiative to introduce Juris Master Degree (JM) to fill this vacuum (Erie, 2009; Landsberg, 2011). The ministries accepted the JM proposal in 1995 and consequently, in 1998 the pilot project was started with the aim to bridge the gap and fulfil the demand of legal profession in China (Erie, 2009). The three years JM programme, modelled on American graduate legal studies, accepts even the graduate students without law degree (Baskir, 2012). The curriculum of the programme was designed "to produce better legal practitioners" and to enhance their legal skills than offered in LL.B, LL.M, or LL.D programmes (Ibid: 171). This initiative shows the governmental efforts to transform the structure of legal education from a predominant undergraduate law major to preponderant professional legal education. However, the aim of legal education and the methodologies used for teaching of legal education in China remain a heated topic among the scholars, educators and researchers (Ling, 2006).

\subsection{Admission to Practice Law in China}

The students who successfully complete the four years of law school study can appear in the annual National Judicial Examination in China (Law of the People's Republic of China on Lawyers, $2007 \S 6$ ). Moreover, the students who hold nonlaw undergraduate degree can also participate in the examination (Ibid: $\S 15$ ). Since 2007, the government also allowed the students from certain areas of the country who have completed three year law degree to appear in this examination (Gao, 2010). National Judicial Examination is uniform across the country and only Chinese citizens are allowed to participate in the exam (Ibid: $\S 5$ ).

Ministry of Justice issues a Certificate of Legal Profession Qualifications to those students who successfully pass the Judicial Examination (Measures for the Implementation of National Judicial Examination, $2008 \S 16$ ). This certificate is typically known as a first step to be a Legal Practitioner in China. In addition, the person should also have one year practicing experience in a law firm and he/she should be a good moral character (Law of the People's Republic of China on Lawyers, $2007 \S 8$ ). The Ministry of Justice is competent authority to decide and grant the lawyer's qualification in certain cases such as if a person has completed undergraduate legal education less than four years, or engaged in legal work such as research and teaching, and have acquired a senior or equivalent professional position (Ibid: § 7). Similarly, the Ministry is competent to prohibit any person to 
practice who is incompetent or who has been criminally punished except minor crimes, or has been sacked from public employment or his/her law practising licence was revoked (Ibid: $\S 9$ ).

\section{Historical Background of Legal Education in India}

Indian legal education has witnessed a long terrible state because of disinterest in changing the structure of legal education at the highest level of society. The apathy explains their blur and posteriority intentions toward the study of law in the country. The lawyers were divided into two categories according to their level of legal training. The ones who studied barrister-at-law in England were called Barristers while the Attorneys did not have proper legal training but were court clerks and conversant with legal process (Morrison, 1972). Before the independence of India, the attorneys also proceeded to England for the training of legal education, which mean the legal profession in India was largely dominated by the English Law degrees (Mukherjee, 2007). The difference between the quality and training of legal education had negative impact on the legal education in India because rich families used to send their children to England to become barristers or attorneys. They were given more respect and superiority upon their return as compared to those who earned their law degrees in India.

This discrimination remained for long time which led the legal education in India turned into part time study rather than a full time study (Aggarwal, 1959). Mostly law schools in the country conducted classes in the evening or at night to give privilege to their students who worked during the day (Ibid: 231-232). These part time law schools hired part time faculty members to keep the cost down because they did not need to pay full salaries. Most of the faculty members were young, inexperienced and they had little interest in teaching since their sole purpose was to increase their meager income (Dasgupta, 2010). Most of the faculty members of law schools were government servants who worked on low level posts, which clearly exhibits lack of interest on part of schools in legal education, legal research and teaching. The existing lassitude of legal education in India was further escalated by the introduction of typical two year law degree programme; the said programme failed to develop the critical thinking and practical skills which are necessary to practice law effectively (Ibid: 433).

Indian legal education had to face many complicated reforms concerning the required qualification to study law. In the West, students would typically complete twelve years of studies in higher secondary school, then further proceed for four years of college education or undergraduate studies. After completing this degree, they can join law school for a graduate programme (Ibid: 434). However, in some parts of India, students can start legal education directly after the completion of higher secondary school education (Jena, 2002). The law degree programme in the 
Yu ShuHong, Malik Zia-ud-Din, Roy Dilawer Khan, Samra Bilal (2018)

Cross-national comparative study on legal education and admission to practice between China, India and Pakistan

United States (US) is typically offered for three years but the duration of law degree varies in India.

The current situation of legal education in India soared up for corrective action, consequently; the Government appointed the first commission in 1948 to improve and revisit the higher education across the board (India, Ministry of Education, 1948). The commission recommended revamping of higher education including legal education in the country. The commission pointed out that legal education and law school lacks full time permanent faculty members. The commission sought to elevate the status of Law Professor equal to professors in Arts and Science. Moreover, the commission stressed upon the need of research capabilities and appropriate facilities such as libraries, contemporary law books and updated law journals in law schools and departments in the universities (Ibid: 60).

The commission distinctly mentioned that the legal research and publication should be focused while it ignores the required improvements in legal pedagogy. A teacher has to be intellectually capable and research-oriented to increase students' ability to think critically and logically. Therefore, the commission strongly recommended reducing the teachers work load which should not be more than eighteen hours per teaching week so that the remaining time should be dedicated for the research work (Ibid: 71). The recommendation made by the commission for the law teachers' could not bring any remarkable change to improve the structure of legal education in India. It was partly due to the fact that commission did not suggest any fundamental changes in legal teaching method and mainly because the recommendations which it made were largely ignored, and the standard of legal education in the country remained appalling due to lack of interest and leadership (Varkey, 1991). The reluctance of brilliant minds to join formal legal teaching and a resultant scarcity of competent law teachers is catastrophic for quality of legal education.

The Constitution of India empowers both central and state governments to establish universities for higher studies to instill education including legal education. [3] But the central government is competent to coordinate and determine the higher education standards offered in any institutions around the country. Likewise, the authority to legislate on legal profession and legal education is contained in the concurrent list of the constitution, which empowers the central and state governments to develop the structure and objective of the education and methods of instilling education including legal profession and learning. It also empowers the universities to introduce different law courses and curriculum of these courses. The University Grant Commission (UGC) was established though a Central Act promulgated in 1972, which authorizes to regulate and formulate the standards of legal education (India, The University Grant Commission Act, 1972 § 12). The Bar Council of India (BCI) was established under The Advocates Act, 1961, which 
specifically empowers the bar to specify standard of legal profession and legal education (India, The Advocates Act, $1961 \S 7(\mathrm{~h}) \&$ (i)). The act empower the Bar Council to formulate rules and regulations for the legal education which are to be followed by all universities for imparting legal education (The Bar Council of India Rules 1964 (Part IV). Surprisingly, the aims and objectives for imparting legal education of both BCI and UGC are not similar and consistent; therefore the conflict was witnessed between these institutions. [4] The universities and other educational institutions emphasized on the social purpose of law and science of law while neglecting the professional and clinical education of law (Varkey, 1991) while the main focus of Bar Council mainly on professional and practical aspects of legal education.

The Advocate Act 1961, which mandated the Bar Council of India (India, The Advocates Act, 1961) to "promote and support law reform" (Ibid: $§ 6$ (e)), also authorizes the BCI "to conduct seminars and organize talks on legal topics by eminent jurists and publish journals and papers of legal interest" (Ibid: $§ 6$ (ee)) and allows "visiting and inspecting universities...". (Ibid: $\S 6$ (gg)). The Bar Council was empowered "to promote legal education and to establish standards in consultation with Indian universities and the State Bar Councils..." (Ibid: § 7 (h)). Moreover, the act empowers the bar council "to recognize universities whole degree in law shall be qualification for enrolment as an advocate...." (Ibid: $§ 7$ (i)). The powers granted to the Bar Council of India to recognize law schools and lay down the standards of legal education seemed in conflict with The University Grant Commission Act, 1956 (Dasgupta, 2010).

The University Grants Commission Act 1956 empowered the commission to determine the standards of legal education for the national universities which creates the conflict and overlapping of power as to which institution is legally obligated to regulate legal education in India. Because the council can recognize those universities to grant law degree but those universities did not comply with commission's necessary requirements. The Council is empowered to control the eligibility of legal profession and determine the standards of legal education while the commission is mandated to determine the legal pedagogy (Law Commission of India, 2002).

Eventually, both institutions e.g. (Bar Council of India and University Grants Commission of India) agreed to work together for the improvement of legal education in the country. Then, the council appointed a Curriculum Committee for the development and improvement of LL.B. and LL.M. syllabus. The Commission and Council worked together for the development of legal education. Both institutions further agreed that the council will provide the curriculum and the course content will be left upon the universities discretion. This reciprocal agreement was recognized by the Commission's Curriculum Development 


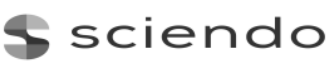

Yu ShuHong, Malik Zia-ud-Din, Roy Dilawer Khan, Samra Bilal (2018)

Cross-national comparative study on legal education and admission to practice between China, India and Pakistan

Committee in 1988 and 2001 (UGC, Curriculum Development Committee, Law Report, 2001).

\subsection{Basic Structure of Legal Education in India}

The Bar Council of India exercises its power to determine the standards of legal education and to recognize colleges teaching law degree under the Advocates Act 1961 (Varghese, 2010). Legal education is a shared responsibility of two institutions i.e. Bar Council of India and University Grant Commission, which is quite similar to Ministry of Education and Ministry of Justice in China. Both jurisdictions have same tensions and problems in relation to the supreme authority over legal education, education standards and college or university recognition to award of law degree such as JM degree programme in China (Flood, 2011). Many universities have affiliated law schools or colleges approved by the BCI and UGC but most of them are inefficient and incompetent in providing legal education (Varghese, 2010). Bar Council of India has approved about 900 to 1000 law colleges and universities which are graduating thousands of students every year. These colleges and universities can be divided into three classes: private global law schools (Jindal Global Law School); National Law Schools (Bangalore etc); and Provincial Law Colleges, many of which are private owned colleges.

The Bar Council of India is mandated to prepare the syllabus for legal education which covers the wide range of legal topics for LLB, LLM and PhD degrees (Law Commission of India, 2002). The BCI has recognized two different routes for law degrees for freshmen. The first entry point is to take a three years LLB degree after graduate degree in any arts, science and commerce subject. The second entry point is to take joint BA-LLB degree for five years after completion of twelve years of education. Legal education imparted through three years LLB degree or five years LLB degree aims to prepare law graduates to be able to provide legal advising and law practice in the courts; to acquire legal education to find employment in public or private sector; and to acquire higher legal education to become a law instructor or a prominent jurist (Jena, 2002).

Thus, the objective of imparting legal education was to develop professional skills in students. But the rules recommend compulsory and optional courses only to be taught in LL.B syllabus, without emphasizing on the practical aspects of legal studies (Varkey, 1991). Likewise in China, many of these courses were based on traditional topics without clear guideline relating to the curriculum planning and development. The teaching methods were also traditional namely classroom lectures, tutorials, moot courts and case study methods. However, the curriculum lacks the mandatory requirement to be instilled in a student to become a competent lawyer and to comprehend the social dynamics of the society (Ibid: 450). 

Pakistan

The Bar Council of India introduced new regulations on legal education by establishing five years LLB course after twelve years of education in 1982. The proposed pre-law courses for the first two years consist of Political Sciences, Economics, Sociology, History and Language. [5] Most importantly, the courses like Administrative Law and Public International Law are also included in the courses contents as compulsory courses. The inclusion of such courses intends to enhance the standards of legal profession and legal education in the country. However, universities ARE given autonomy to introduce non professional and non academic law courses in the course contents of legal study. The major difference between three year LL.B courses and five years integrated courses are based on numerous factors which can be seen in the professional legal education, professional legal development of students, knowledge on multi-pronged disciplines, legal training and clinical legal education (Ahmad, 2009).

\subsection{Admission to Practice Law in India}

The Advocates Act 1961 stipulates that a person admitted to practice should have Indian nationality (India, The Advocates Act, $1961 \S 24$ (a)) and should hold a law degree (Ibid: $\S 24$ (c)). The Bar Council of India considerably controlled the content of the law degree because this is the main requirement for the admission to practice (Schukoske, 2009). The BCI introduced the All India Bar Examination for all law graduates who seek admission to practice in order to skim skilled and quality lawyers for the society as well as the country (Varghese, 2010). The bar exam is conducted twice in a year which is based on multiple choice questions focusing on law school curriculum. However, it is noteworthy to mention that BCI exempts law graduate from the training of certain period under the supervision of senior lawyer or with law firm as it is compulsory in China.

\section{Historical background of Legal Education in Pakistan}

The legal system of Islamic Republic of Pakistan is based on the common law of England and Wales. The British law remained in force till the independence of Pakistan in 1947. After the independence, the Government of India Act 1935 was retained as a provisional Constitution of the country (Hussain, 2011). Thus, ultimately the judicial system of British period continued with due adaptations and modifications in the newly established state. The authority and jurisdiction of Supreme Court, Federal and Provincial High Courts remained intact as prescribed in the Government of India Act 1935. However, Islamic Sharia Law was incorporated into Pakistani Law which led to the creation of Federal Shariat Court during military regime of General Muhammad Zia-ul-Haq in 1980s.

The political and constitutional evolution of Pakistan has been controlled by several military coup d'état; the most recent military coup occurred in 1999 (ADB, 
Yu ShuHong, Malik Zia-ud-Din, Roy Dilawer Khan, Samra Bilal (2018)

Cross-national comparative study on legal education and admission to practice between China, India and Pakistan

2000). Pakistan is seventh nuclear power in the world which is geopolitically significant. But the state has many problems roaming from weak democratic culture, religious radicalism, and economic instability to institutional decline and increased lawlessness. This critical situation has made the Pakistani justice system overloaded and handicapped because of the regressing quality and deteriorating professionalism of legal system and experts (Siddique, 2007).

Since the creation of Pakistan, the legal education has continuously declined rather than strengthening of professional standards and academic excellence. The quality of legal education and its output do not accomplish the legal profession and academic commitments. Consequently, the legal education in Pakistan is not producing well versed and trained lawyers, judges, legal scholars, and other law trained personnel to meet the legal, social, cultural, economical and civil governance' demands, and to avoid abuses of rights that country and people face (ADB, 2000). The crisis in legal education has been a serious matter of discussion in different countries and jurisdictions over the past few decades (Maleshin, 2016). In Pakistan, the development of legal education has fallen behind compared to other areas of academic development (Braibanti, 1999). The weakness of legal education and legal profession is an underlying challenge for the rule of law in Pakistan. The substandard quality of legal education, the lack of professional standards and nonexistence of clinical legal education are contributing to the deficiency of the legal experts (prosecutors, lawyers, judges); and is ultimately weakening the confidence of general public on rule of law (Blue, Hoffman, \& Berg, 2008). The legal profession is poorly regarded and opted as last opportunity especially for the students who are unable to pursue better position in other professions (Ranjha, 2015). However, there are few lawyers who earned high respect due to their foreign qualification and work in renowned law firms (ADB, 2000).

The legal education is in a colossal mess at all levels in Pakistan due to the lack of attention by both universities and professional bodies which terribly affected the existing structure and standards of legal education (Khan, 2003). The lack of high quality law schools and deterioration in the quality of legal education was taken notice by the Supreme Court in the case of Pakistan Bar Council vs Federation of Pakistan. The court gave its remarks on the substandard quality of legal education in the country and stated: "The poor quality of legal education in the country is taking its toll on the Bench, the Bar and ultimately the quality of justice" (PBCv $F o P$, 2007). Therefore, it is imperative to transform the fundamental structure of legal education while reshaping it in line with international standards. Similarly, "the mushroom growth" of private law colleges affiliated with universities apart from the public universities schools or colleges has to be reviewed (Sedgwick, 2005). Currently, there are more than 137 law colleges in the country; out of these 


\section{sciendo

Yu ShuHong, Malik Zia-ud-Din, Roy Dilawer Khan, Samra Bilal (2018)

Cross-national comparative study on legal education and admission to practice between China, India and Pakistan

Punjab province is leading with 85 colleges; Khyber Pakhtunkhwa province has 21; Sindh province has 18 and Baluchistan province has 3; Federal area has 5 and Azad Jammu and Kashmir has 2 colleges (Hussain, 2011).

\subsection{Basic Structure of Legal Education in Pakistan}

Similar to India, the Higher Education Commission (HEC) and Pakistan and Provincial Bar Councils (PBC) and Islamabad Bar Council are authorized to impart legal education, inspect, evaluate and conduct quality control and assessment of law colleges and universities in Pakistan (Pakistan, Legal Practitioners and Bar Councils Act, $1973 \S 13$ ). The overlapping authority of both Bar Council and Higher Education Commission has undermined the implementation of rules and regulations to impart legal education in the country (Siddique, 2014). However, the Bar Councils have the dominating role to determine and regulate the instructions of legal education in the country. The current situation has worsened the quality of legal education in the law colleges and universities. Meanwhile, many law colleges have been established with no permanent faculty, no standard curriculum, and absence of research atmosphere and even sometime without regular classes (ADB, 1999). The graduates from such colleges lack legal understanding, professional training and analytical skills and thus, result in increasing the gap between the professionalism and rule of law in the country.

During the 1960s the legal education was dominated by public sector universities in the country. While there was a significant shift which gave boost to private sector law colleges affiliated with Public Sector University (Sedgwick, 2005). This development occurred due to the following reasons; i) the growth and capacity of public sector law colleges/ universities was less than the growth of population in the country. The growing demand has made this sector more productive for the entrepreneurs to establish private law colleges; ii) Legal education is versatile and dynamic area of study tendering professional access to numerous opportunities. Many people who have no intention to continue the legal profession, took the legal education to increase their employment opportunities especially before 1993, because the-then LL.B degree was only a two years programme, which did not require a lot of effort and analytical study to pass [6]; iii) Many retired as well as in-service civil servants from public and private sector took LL.B examination and entered into this profession (Siddique \& Laws, 2007). This also proved a stimulus for private law colleges to take roots in the country since attending classes in such institutes was practically not mandatory.

Currently, there are two types of law degree programmes in Pakistan. The first type of law degree consists of three years of LL.B after completion of graduation (14 years) with science or arts major. The second type of law degree programme consists of five years of BA-LL.B or LL.B (Hons) after completion of Higher 
Yu ShuHong, Malik Zia-ud-Din, Roy Dilawer Khan, Samra Bilal (2018)

Cross-national comparative study on legal education and admission to practice between China, India and Pakistan

Secondary Education (12 years) with science or arts courses major. Both types of legal studies follow the curriculum and syllabus prescribed by the Higher Education Commission of Pakistan, Pakistan and Provincial Bar Councils (PBC) (Siddique, 2014). Both national and provincial bar councils are responsible for the accreditation of law schools, curriculum design and standards setting of legal education and professional ethics. The curriculum for the three-year and five-year programmes lacks contemporary research courses necessary for the analytical underpinning of the students. Instead, the curriculum only covers introduction to the statues and administrative courses (QAU, 2017). Meanwhile, there are two universities Islamic- International University and Lahore University of Management Sciences each from public and private sector- offering special composite LL.B degree that covers additional courses apart from the courses recommended by the Pakistan Bar Council (IIUI, 2017; LUMS, 2017). The graduates from these universities can be regarded as a separate breed altogether. Apart from the LL.B degree, LL.M and PhD degrees are also offered by the public sector universities (IIUI, 2017).

The pedagogical method in Pakistan consists of lectures presentation of relevant codes and students are required to memorize them. The faculty members seldom have practical legal experience; thus most of them lack pedagogical training and academic research (ADB, 2000). The Higher Education Commission (HEC) is the funding and regulatory body for the public universities in the country. The commission has not shown significant interest in promoting and supporting legal education in the country. Mostly state law schools are underfunded and ignored; they are unable to provide encouraging environment for strengthening and capacity building of indigenous faculty and qualitative research. On the contrary, private law schools entered into this business for the pursuit of profit and they have ignored the quality of legal education. The absence of legal academia elevated the lack of quality institution that could have increased the standards of legal education; it has, in turn, deteriorated the availability of rights and justice to the nation (Siddique, 2013).

Consequently, both practicing lawyer and judges have entered in the teaching profession as part time teacher with extremely low research background and interdisciplinary aspects of law. The instruction method of such faculty members follows only presenting statues as axiomatic facts and thus neglecting the conceptual and philosophical background of statutory laws (Siddique, 2007). Their teaching method merely focuses on theoretical discourses while ignoring the interdisciplinary aspect of laws with social, political, economic and cultural aspects. However the ultimate purpose of law schools is to impart legal training, to develop critical, analytical and comparative approach and to ensure that the 
Yu ShuHong, Malik Zia-ud-Din, Roy Dilawer Khan, Samra Bilal (2018)

Cross-national comparative study on legal education and admission to practice between China, India and Pakistan

students have covered as many statutes as possible during the course of LL.B degree.

\subsection{Admission to Practice Law in Pakistan}

A person who has successfully completed LL.B degree is eligible to be enrolled to appear in the bar council exam for the licence to practice law in the country (Pakistan, Legal Practitioners and Bar Councils Act, $1973 \S 26$ (C) (iii)). In addition, the student is required to have six months training under the supervision of senior lawyer to appear in the bar examination (Warraich, 2013). However, the training condition is not applicable to the students who are given exemption by Pakistan Bar Council (Pakistan, Legal Practitioners and Bar Councils Act, $1973 \S$ 26 (d)). The bar council entrance exam to become a lawyer is held twice in a year. The experimental training of law graduates in Pakistan is entirely impromptu and unplanned (Rahim, 2014). The Federal and Provincial Bar Councils are responsible to hold the bar examination in each provinces. A foreigner can also be enrolled as lawyer in Pakistan after lapse of one year residence in the country (Pakistan, Legal Practitioners and Bar Councils Act, $1973 \S 26$ (a).

\section{Comparative Analysis and Conclusion}

The study reveals three different pathways to admission existing in these three jurisdictions:-

- A uniform National Judicial Bar Examination with one year compulsory training under a senior lawyer or at a law firm (China);

- A uniform Bar Examination with no practical training (India);

- A bar examination along with six month mandatory practical training experience under the supervision of a senior lawyer or with a law firm (Pakistan).

It is pertinent to mention here a distinctive aspect between India and two other jurisdictions. China and Pakistan have two-tier entry system to admission for practice after graduation. China and Pakistan have one year and six months mandatory training under a senior lawyer or with a law firm respectively whereas India doesn't have any provision of training similar to its counterparts. After the successful completion of training, the graduates are required to appear in the bar examination. The bar examination is exhaustive, rigorous and competitive, and not all candidates can pass this exam. The successful candidates are allowed to apply for the unlimited practice certificate.

This obligatory training strengthens the ability and enriches the knowledge of young graduates under the supervision of senior lawyers. However, there is no such compulsory training course provided by the law schools or third party such as in USA and Australia. These courses are designed to help the graduates to prepare for practice instead of assessing their competence or quality. However, an imperative 
Yu ShuHong, Malik Zia-ud-Din, Roy Dilawer Khan, Samra Bilal (2018)

Cross-national comparative study on legal education and admission to practice between China, India and Pakistan

point to discuss here that none of the jurisdictions offers any mandatory training course in the curriculum to the law graduates. The absence of such training course is causing and allowing inefficient, incompetent and inexperienced lawyers to join the legal fraternity.

A cardinal question to discuss is whether the professional practical training should perform as second gatekeeper to assure the competence of law graduates or such professional training should be considered as preparatory courses for admission to bar and legal profession as in China and Pakistan. Subsequently, a fundamental question arises whether the supply of lawyers should be regulated by the state or by the market. Both approaches are perceived to have their inherent weakness. The first approach is perceived to restrain the number of entrants into the market and provides protection for the existing lawyers. On the other hand, it raises concerns for the rights of graduates to enter into legal profession. The second approach is likely to worsen the quality and competence of lawyers and legal profession, and it also limits the opportunities for the lawyers who already have admission to bar. Certainly, the concern on limited availability of job opportunities has been enlarged as a result of increase in number of law schools, while fresh law graduates have fewer opportunities in practice. Additionally, the legal profession is in trouble to retain good lawyers to deal with increasing competition in the global market.

However, several interesting countervailing tendencies and contradictions have emerged from the above investigation. Firstly, the law degree has become a liberal arts degree rather than a profession degree over the past couple of decades or so in all jurisdictions and has turned incoherent from the legal practice in many aspects. The legal profession is expected to fulfil its ultimate purpose of preparing legal professionals and graduates for practice, which has not been achieved in the countries studied in this paper. As mentioned above, this result occurred due to the increased competition in this profession which decreased the opportunities for the young lawyers to receive on-job training, and consequently it required the junior lawyers to develop the practical skills.

Secondly, the past two decades have witnessed substantial increase in the rigor and systematization of professional legal training courses before admission to bar and the need to incorporate practical skills into the curriculum of law schools. The discussion in the Part-2 discloses that legal profession has extensive expectations from the academic degree. There may have difficulties while distinguishing the professional training courses and law degree. Regardless of the rigour with which professional or vocational training is delivered to the law graduates, it is further considered that much could have been done as it yet to be done in terms of incorporation of practical skills into the law curriculum and preparing law graduates to practice. 

Pakistan

Thirdly, many governments and markets around the globe increasingly require the legal profession to be carried out as a regular service industry. However, countervailing aspects exist in some of the jurisdictions as legal profession follow through by a traditional prospect of this profession or occupation, that admissions to bar should only be allowed upon acquiring minimum level of competency and quality standards to protect the public interest. The bar entrance exam is performing the function of second gatekeeper in two of the jurisdictions i.e. China and Pakistan. All jurisdictions must change the content of the bar examination from code-centric to case-centric. This would make the exam more competitive for the candidates who simply remember the rules without bothering to understand them. Fourthly, competition often comes into play in respect to admission requirements by focusing on the need, on the contrary, the process to meet the access requirement and, to assure that the minimum level of competence and quality has been achieved. The first access to need functions against protectionism and favouritism allows the market to regulate the members. The second need (i.e. assuring the minimum level of competence and quality) positively functions in relation to treating legal profession as special profession while supporting the argument of appropriateness of second gatekeeper. However, the concept of second gatekeeper is to strengthen the skills and respond to the globalization of legal education and legal practice.

Last but not the least, it is strongly suggested that legal education should not be separated from the legal practice in its countless forms and contexts. Students' legal skills should be strengthened through incorporating different teaching methods, for example through case-studies, dialogues, clinic teaching methods, simulations, and specific dispute-resolution workshops. Most importantly, the schools should critically focus on the substantive law to increase the ability of general analytical skills such as problem solving and research, and should also keep in mind the relevance of subjects to legal practice while selecting them. The law schools are required to do their best what they always have done to teach legal doctrine in a rigorous way and strengthen the students' ability to develop analytical and problem solving skills. There should be a balance in the curriculum between transactional and clinical subjects and also between these two aspects and the critical legal theory. These suggestions, if implemented, shall develop a creed of legal graduates with practical professional skills which are deemed necessary for the betterment of legal profession as well as to fulfil the global demand.

\section{Acknowledgement}

Research for this article was supported by the Ministry of Education, China, Youth Project of Humanities and Social Sciences (Project No. 17YJC820001). 


\section{References}

1. Abramson, K. (2006). Paradigms in the Cultivation of China's Future Legal Elite: A Case Study of Legal Education in Western China. APLPJ, 7, 302.

2. Aggarwal, A. P. (1959). Legal Education in India. J. Legal Educ., 12, 231.

3. Ahmad, T. (2009). Legal Education in Indian Perspective.

4. Arthurs, H. (2001). The world turned upside down: are changes in political economy and legal practice transforming legal education and scholarship, or vice versa? International Journal of the Legal Profession, 8(1), 11-21.

5. Asian Development Bank (ADB). (2000). Law and Policy Reforms

6. Baskir, C. E. (2012). Crossing Borders: Creating an American Law Clinic in China.

7. Blue, R., Hoffman, R., \& Berg, L.-A. (2008). Pakistan Rule of Law Assessment-Final Report. Prepared for the USAID/Pakistan by Management System International. Washington D C.

8. Braibanti, R. (1999). Cornelius of Pakistan: Catholic chief justice of a Muslim state. Islam and Christian-Muslim Relations, 10(2), 117-157.

9. Dasgupta, L. (2010). Reforming Indian legal education: Linking research and teaching. Journal of Legal Education, 59(3), 432-449.

10. Erie, M. S. (2009). Legal Education Reform in China Through US-Inspired Transplants. Journal of Legal Education, 59(1), 60-96.

11. Faulconbridge, J. R., \& Muzio, D. (2009). Legal education, globalization, and cultures of professional practice. Geo. J. Legal Ethics, 22, 1335.

12. Feineran, J. V. (1991). Economic and Legal Reform in China, 1978-1991. Problems of Communism, 40(5), 62.

13. Flood, J. (2011). Legal education in the global context: challenges from globalization, technology and changes in government regulation.

14. Gao, J. (2010). Comparison between Chinese and American Lawyers: Educated and Admitted to Practice Differently in Difference Legal System. Penn St. Int'l L. Rev., 29, 129.

15. Godwin, A., \& Wu, R. W.-s. (2016). Legal Education, Practice Skills, and Pathways to Admission: A Comparative Analysis of Singapore, Hong Kong, and Australia. J. Legal Educ., 66, 212.

16. He, W. (2005). China's legal profession: the nascence and growing pains of a professionalized legal class. Colum. J. Asian L., 19, 138.

17. Holmes Jr, O. W. (1886). The Use and Meaning of Law Schools, and Their Methods of Instruction. Am. L. Rev., 20, 919, 921-922.

18. Hussain, F. (2011). The judicial system of Pakistan: Supreme Court of Pakistan.

19. Islamic International University, Islamabad. (2017). Courses offered for BA-LLB programme. Retrieved from http://www.iiu.edu.pk/wp-content/uploads/ downloads/ faculties/fsl/scheme/BA_LLB_2010.pdf

20. Jena, K. C. (2002). Role of bar councils and universities for promoting legal education in India. Journal of the Indian Law Institute, 44(4), 555-568.

21. Ji, W. (2005). Legal Education in China: A Great Leap Forward of. Kobe University law review, 39, 1-21. 
Yu ShuHong, Malik Zia-ud-Din, Roy Dilawer Khan, Samra Bilal (2018)

Cross-national comparative study on legal education and admission to practice between China, India and Pakistan

22. Jiang, D. (2000). Judicial reform in China: New regulations for a lay assessor system. Pac. Rim L. \& Pol'y J., 9, 569.

23. Keyuan, Z. (2003). Professionalising Legal Education in the People's Republic of China. Sing. J. Int'l \& Comp. L., 7, 159.

24. Khan, Ahmed. Legal Education in Pakistan-A Review, retrieved from http://www.supremecourt.gov.pk/ijc/Articles/6/1.pdf (accessed on 09-08-2017)

25. Kosuri, P. (2015). Beyond Gilson: The art of business lawyering.

26. Lahore University of Management Sciences (LUMS) (2017). Courses list of BA-LLB (honors) list. Retrieved fromhttps://sahsol.lums.edu.pk/programmes/ba-llb-honours (accessed on 10-08-2017)

27. Landsberg, B. K. (2011). Promoting social justice values and reflective legal practice in Chinese law schools. Pac. McGeorge Global Bus. \& Dev. LJ, 24, 107.

28. Law Commission of India. (2002). 184th Report on The Legal Education \& Professional Training and Proposals for Amendments to the Advocates Act, 1961 and the University Grants Commission Act, 1956.

29. Law of the People's Republic of China on Lawyers, 2007

30. Lee, L. T. (1962). Chinese communist law: Its background and development. Michigan Law Review, 60(4), 439-472.

31. Legal Practitioners and Bar Councils Act, Pakistan, 1973

32. Ling, M. (2006). Clinical legal education and the reform of the higher legal education system in China. Fordham Int'l LJ, 30, 421.

33. Maleshin, D. (2016). The Crisis of Russian Legal Education in Comparative Perspective. J. Legal Educ., 66, 289.

34. Measures for the Implementation of National Judicial Examination, China, 2008

35. Minzner, C. F. (2013). The rise and fall of Chinese legal education. Fordham Int'l LJ, 36, 334.

36. Ministry of Education, Government of India, The Report of the University Education Commission, 1948, available at http://www.educationforallinindia.com/1949\%20Report\%20of\%20the\%20University\% 20Education\%20Commission.pdf (accessed on 21-05-2017)

37. Morrison, C. (1972). Munshis and their masters: the organization of an occupational relationship in the Indian legal system. The Journal of Asian Studies, 31(2), 309-328.

38. Mukherjee, D. (2007). Law Schools and Legal Education in India.

39. Pakistan Bar Council v Federation of Pakistan, PLD 2007 SC 394

40. Phan, P. N. (2005). Clinical legal education in China: in pursuit of a culture of law and a mission of social justice. Yale Hum. Rts. \& Dev. LJ, 8, 117.

41. Pinguelo, F. M. (1998). The Struggle between Legal Theory and Practice: One Law Student's Effort to Maintain the Proper Balance. BYU Educ. \& LJ, 173.

42. Priest, G. L. (1988). Increasing Division between Legal Practice and Legal Education, The. Buff. L. Rev., 37, 681.

43. Quaid-e-Azam University, School of Law. (2017) Courses Offered for BA-LLB programme. Retrieved from http://law.qau.edu.pk/courses.php (accessed on 10-082017)

44. Rahim, Zarmeeneh. (2014). CPD and Current Challenges: Law Incubators, $2^{\text {nd }}$ National Conference on CPD. 
Yu ShuHong, Malik Zia-ud-Din, Roy Dilawer Khan, Samra Bilal (2018)

Cross-national comparative study on legal education and admission to practice between China, India and Pakistan

45. Ranjha, Ziaullah. (2015, October, 02), Dawn Newspaper, retrieved from https://www.dawn.com/news/1210297 (accessed on 09-08-2017)

46. Schukoske, J. E. (2009). Legal education reform in India: Dialogue among Indian law teachers.

47. Sedgwick, Robert. (2005 January) Private Universities in Pakistan, World Education News and Reviews, retrieved from http://wenr.wes.org/2005/01/wenrjanuaryfebruary-2005-pakistans-system-of-education (accessed on 10-08-2017)

48. Siddique, O. (2007). Marital Law and Lawyers: The Crisis of Legal Education in Pakistan and Key Areas of Reform. Regent J. Int'l L., 5, 95.

49. Siddique, O. (2013). Pakistan's experience with formal law: an alien justice: Cambridge university press.

50. Siddique, O. (2014). Legal Education in Pakistan: The Domination of Practitioners and the" Critically Endangered" Academic. Journal of Legal Education, 63(3), 499-511.

51. Siddique, O., \& Laws, M. (2007). Lawyers: The Crisis Of Legal Education In Pakistan And Key Areas Of Reform, 5 Regent J. Paper presented at the Int'1 L.

52. Stuckey, R. (2016). The American Bar Association's New Mandates for Teaching Professional Skills and Values: Impact, Human Resources, New Roles for Clinical Teachers, and Virtual Worlds. Wake Forest L. Rev., 51, 259.

53. Susskind, R. E. (2013). Tomorrow's lawyers: An introduction to your future: Oxford University Press Oxford.

54. The Advocates Act India, 1961

55. The Bar Council of India Rules 1964

56. The University Grant Commission Act of India, 1972

57. University Grant Commission. (2001). Curriculum Development Committee Law Report.

58. Varghese, J. (2010). Global Legal Education and India-A Blueprint for Raising Indian Legal Education to Global Standards.

59. Varkey, A. (1991). Learning Objectives of Legal Education in India: A Critique. Cochin University Law Review, 15, 444-454.

60. Wang, Z., Liu, S., \& Li, Z. (2016). Internationalizing Chinese Legal Education in the Early Twenty-First Century. J. Legal Educ., 66, 237.

61. Warraich, A. N. (2013). The legal framework to inculcate CPD in Pakistan. Paper presented at the First national conference on CPD in law.

62. Xianyi, Z. (2001). Legal Education in China. S. Tex. L. Rev., 43, 707.

63. Zhu, S. L. (2009). An institutional inquiry into legal skills education in China. Pac. McGeorge Global Bus. \& Dev. LJ, 22, 75

\section{Notes}

1. Chinese legal Education has been in a serious turmoil before Cultural Revolution, however, it resumed with the approval of national entrance examination in 1977-1978. 
Yu ShuHong, Malik Zia-ud-Din, Roy Dilawer Khan, Samra Bilal (2018)

Cross-national comparative study on legal education and admission to practice between China, India and Pakistan

2. A comparative study was conducted on total credit required for undergraduate law programme between nine universities. The result reveals that a large number of compulsory courses are being offered whereas very little time is given for specialised law courses and training programmes.

3. The Constitution of India, Schedule 7, List I, Entries 63, 64 and 65, sanctions the Central Government to establish by law educational institutions, including institutions for professional training and research, of national importance: Education and legal profession falls within the concurrent List, which means State Governments can also establish universities and institutions imparting legal education and training.

4. A case was reported against the decision taken by the Central Government for abolishing the professional examination admission to the bar conducted by the Bar Council under The Advocates Act, $1961 \S 49 \mathrm{~A}$. The Maharashtra State Bar Council unanimously passed a resolution against this decision.

5. The aim of National Law University, Delhi is to impart high quality interdisciplinary legal education with a view to produce leading professionals, scholars and academicians particularly in law and generally in other disciplines. The roadmap of the five year BA.LL.B degree programme is available at http://nludelhi.ac.in/acd-cur-ba.aspx (accessed on 01-06-2017).

6. The legal education has been varied from two to three years in the country time to time. It is worth mentioning that tremendous turnover in the legal profession has been observed since many law graduates drop out the profession within five years. 